\title{
The Constitutional Basis of the State-Church Relationship in Argentina - National Patronage ${ }^{1}$
}

\author{
Marta Zuzanna Osuchowska (iD) https://0000-0001-9950-7458 \\ University Cardinal Stefan Wyszyński in Warsaw (UKSW) \\ Faculty of Law and Administration \\ e-mail: m.osuchowska@uksw.edu.pl
}

\begin{abstract}
The constitution of Argentina from 1853 formally introduced the patronage of the Argentine legal system. Its foundations are to be found in the royal patronage, granted by the popes to the kings of Spain from the beginning of their presence in America. The issue of national patronage in Argentina was completed by signing the concordat in 1966. The removal of the constitutional provisions concerning patronage occurred with the constitutional reform in 1994. This institution has been the basis for the regulation of the relationship between the state and the Catholic Church throughout its application. Political proposals for its changes were the basis for the vision of the state presented by successive authorities.
\end{abstract}

Keywords: patronage, Argentina, constitution, Catholic Church, concordat

Słowa kluczowe: patronat, Argentyna, konstytucja, Kościół katolicki, konkordat

\section{Introduction}

Analysis of the institution of patronage requires a comprehensive approach to the issue of the interference of secular authorities in the activities of the Church. This can be treated more broadly as a doctrine undermining the sphere of its independence, which consequently gives the state the right to influence spiritual and ecclesiastical matters, with regard to the organisation of worship and the administration of goods. ${ }^{2}$

1 The project was financed from the funds of the National Science Center (Narodowe Centrum Nauki) granted on the basis of decision number DEC-2017/01/X/HS5/00721 MINIATURA 1.

2 J. Casiello, Iglesia y estado en la Argentina. Regimen de sus relaciones, Buenos Aires 1948, p. 45. 
In this context, the starting point is the policy of regency and its ideological foundations. $^{3}$

The creation of the patronage right is connected with the person of Pope Alexander III (1159-1181) as the author of most of the regulations regarding this issue, which came to Corpus Iuris Canonici (Decree of Gregory IX, 1227-1241). Regulations regarding the patron's rights, which have been constituted in ecclesiastical law since its inception, have been compiled in the Code of Canon Law (CCL) of 1917 - these regulated the existing law and simultaneously prohibited it from being broadcast in the future regardless of the title. In addition, it imposed an obligation on the Ordinaries to persuade patrons to surrender their powers, accepting spiritual rights instead. ${ }^{4}$

The legal definition of patronage in canon law is specified in can. 1448 CCL from 1917 as "a set of privileges with certain encumbrances" (summa privilegiorum cum quibusdam oneribus). ${ }^{5}$ This consisted of the rights and obligations that the founder and his heirs were entitled to in relation to the church beneficiary because of the transfer of land for the church and the salary for its maintenance and construction. An important element was the right to present the clergymen on a vacant beneficiary for approval of the appropriate spiritual authority (ius praesentandi). Other privileges were denoted in documented agreements between the parties, e.g. the right of precedence (ius processionis), or the possibility of asking the beneficiary for maintenance resources in the event of falling into poverty (ius alimentationis) ${ }^{6}$

The code (can. 1448-1471) regulated only the patronage law and the rights and obligations arising from it which were created before its entry into force. The Church consistently sought to repeal it, limiting particular arrangements in the concordat agreements. Ultimately, this law was abolished after the Second Vatican Council, and the current CCL no longer raises this issue. ${ }^{7}$ The law of patronage, as a result of many abuses, in practice had already disappeared before Vaticanum II. ${ }^{8}$ They consisted of the fact that they were given to friendly people for the purpose of obtaining benefits, but this was not legal. As a result of the patronage, the autonomy of the Church was limited in some way by patrons. In turn, it played the role of national policy for the state. The patronage of public law should be distinguished, rights exercised by the king and the patronage of private law, which was vested in private individuals, most

${ }^{3}$ Followers of the regalism repeat arguments regarding the lack of sovereignty of the temporal Church, the need for compensation in exchange for state protection as well as the lack of opposition or tacit approval of the Church for state actions undertaken in the area of its activity.

${ }^{4}$ The very name "patronage" derives from the institution dating back to the beginnings of ancient Rome - the layout between the patron and the person giving himself under his protection, based on mutual fidelity.

${ }^{5}$ Codex Iuris Canonici Pii X Pontificis Maximi iussu digestus Benedicti Papae XV auctoritate promulgatus, 26.05.1917, AAS 9 (1917), pars II, pp. 1-593, can. 1448: "Ius patronatus est summa privilegiorum, cum quibusdam oneribus, quae ex Ecciesiae concessione competunt fundatoribus catholicis ecclesiae, cappellae aut beneficii, vel etiam eis qui ab illis causam habent."

${ }^{6}$ R. de Lafuente, El patronato y el pase o "exequatur" argentinos, [in:] La doctrina católica en el desenvolvimiento constitucional argentino, A. Caggiano (ed.), Buenos Aires 1957, pp. 205-206.

7 The Holy See now uses the Decree on the Pastoral Office of Bishops in the Church "Christus Dominus" and motu proprio "Ecclesiae Sanctae" issued by Pope Paul VI on August 6, 1966.

${ }^{8}$ M. Dyjakowska, Privilegium odiosum. O znaczeniu kontekstu w przekładzie terminologii prawniczej, "Roczniki Humanistyczne" 2013, t. LXI, no. 8, pp. 149-152. 
often founders of places of religious worship. ${ }^{9}$ The subject matter concerns the issues related to the very essence of the Church, namely the scope of power, governance and the foundation of spiritual sovereignty.

The patronage should, in a broad sense, be defined as the intervention of civil authority in ecclesiastical matters, more precisely, as the participation of the state in the appointment of ecclesiastical authorities. However, the Catholic Church has always taught, according to the evangelical guidelines, that the Pope, as the vicegerent of Jesus Christ, is only entitled to appoint institutions and designate candidates for ecclesiastical positions. Therefore, no secular power can apply for the right to intervene in this matter because the actions of the Church are based on divine law. Exceptionally, if in special circumstances a state body could have the possibility of its own activity in this sphere, it would result only from receiving the detailed and specific right to do so from the Church. ${ }^{10}$

Although the patron's right was limited to the presentation of the candidate in order to fill the vacancy without giving any benefits in the exercise of ecclesiastical jurisdiction. It was to a greater or lesser extent a form of foreign intervention that could limit the Church's freedom in the sphere of church norms of competence.

The main aim of the study is to present the issue of the right of patronage in Argentina as an institution having its source in constitutional norms. The study adopted historical-legal and formal-dogmatic methods.

\section{Royal patronage}

The patronage was the privilege granted by the Pope to the Spanish monarchs. Under these powers, royal prerogatives included the appointments of the highest ecclesiastical dignities and the exercise of supervision over them, including the use of material goods and the collection of appropriate fees. The Pope's decision can be mainly justified by the fact that the undertaking of a spiritual conquest involving territories and populations unknown at that time had to be guaranteed both legally and financially. Otherwise, the intended goal could be successfully achieved. However, the huge distances between the colonies of the Holy See and the complexity and size of the enterprise fully justified the decision of the Church to delegate its rights. Assistance in converting indigenous peoples to Christianity and the possibility of acquiring new territories as Catholic lands gave a sufficient guarantee for the controversial and long-term effect of the Pope's decisions. In no way did this diminish papal authority, which is inalienable by its very nature, and gave the possibility of subjugating Christianity to the American city of Rome. The activities of the Spaniards were only a tool to achieve this goal. ${ }^{11}$

\footnotetext{
${ }^{9}$ Patronage cannot be invoked by any state and its secular power as a right belonging to authority, but only as a special privilege from the Church which is given explicitly.

${ }_{10}$ J. Buteler, Patronato, Córdoba 1892, pp. 19-23.

${ }^{11}$ C. Bruno, El derecho público de la Iglesia en la Argentina, Buenos Aires 1956; J. Casiello, Iglesia y estado en la Argentina, régimen de sus relaciones, Buenos Aires 1958; F. Legón, Doctrina y ejercicio del patronato nacional, Buenos Aires 1920.
} 
The Spanish monarchs, who were given the nickname "Catholic kings" due to the zeal with which they defended religion, maintained close contacts with the papal authority. ${ }^{12}$ The beginning of cooperation on issues of the New India colonies should be date back to the pontificate of Pope Alexander VI (1492-1503), who divided the spheres of influence in the New World between the rulers of Portugal and Spain, issuing the Inter caetera bull, on 4 May 1493, which imposed on the monarchs the obligation to provide benefits for missionaries. ${ }^{13}$ In 1501 , the Pope himself approved the right to collect rents and tithing from churches in the New World but with the obligation to devote them to the evangelisation of the Indian population. ${ }^{14}$ The foundations under the "Royal patronage of India" (Regio Patronato Indiano) were formed by Pope Julius II (1503-1513) with the Universalia Eccleaiae Regiminis bull of 28 July 1508 , which was the first normative regulation of the powers of Spanish kings. ${ }^{15}$ This document gave many benefits to the Crown. This was caused by the lack of financial resources on the part of the Pope. He was unable to prepare a trip to New India, let alone organise an ecclesiastical structure and religious teaching there. ${ }^{16}$ The document itself refers to the actions taken by the Spanish monarchs in defence of the faith, including the overthrow of the Moorish rule of the Iberian Peninsula, which justifies the patronage of the bill. ${ }^{17}$

From the moment when Moorish rule was overthrown, it can be concluded that the structure of a particular church in the Spanish colonies was included in the royal administration. In the Recopilación de las leyes de los reinos de las Indias legislation collection, published by King Charles II of Spain in 1680 in the first book on church law ("Holy Catholic Faith"), ${ }^{18}$ the Church appears as a state-dependent institution. The king positioned himself among the units of the administration of secular authority. The legal bases for the exercise of patronage was assigned to the Spanish crown and its representation in the New World (vice-kingdom and audiences) were enforced in practice.

The relationship between the Kingdom of Spain and the Holy See, which arose as a result of the application of patronage, has not always remained within its established limits in practice, and the actions were not taken with mutual understanding.

12 J. Casiello, El problema de la coexistencia y de las conexiones entre la soberanía temporal y la soberanía espiritual y su solución en el caso argentino, Córdoba 1948, p. 44.

13 A. García-Gallo, Las Bulas de Alejandro VI y el ordenamiento juridico de la expansión portuguesa y castellana en África e Indias, "Anuario de Historia del Derecho Español” 1958-1959, nos. 27-28, pp. 461-830; T. Duve, El Tratado de Tordesillas: ¿Una 'revolución espacial’? Cosmografía, prácticas jurídicas y la historia del derecho internacional público, "Revista de Historia del Derecho" 2017, no. 54, pp. 77-107.

${ }^{14}$ Bull "Eximiae devotionis sinceritas," 16 November 1501.

${ }^{15}$ Derecho y religión. Derecho eclesiástico argentino, J.G. Navarro Floria, N. Padilla, O. Lo Prete (eds.), Buenos Aires 2014, pp. 49-52.

${ }^{16}$ P. de Leturia, El origen histórico del Patronato de Indias, [in:] Relaciones entre la Santa Sede e Hispanoamérica: Vol I, Epoca del Real Patronato 1493-1800; 1493-1800, Época del Real Patronato, Romae-Caracas 1959.

17 T. Fernández de Landa, Las relaciones entre la iglesia y el estado, Buenos Aires 1958, p. 80.

${ }^{18}$ Holy Catholic Faith (Santa Fé Católica) - refers to religious matters, such as patronage, church organisation, the situation of clergy (including monks), aspects related to culture and education. 
There were frequent conflicts which in fact reflected the traditional division in the understanding of the nature of patronage, between supporters only for the exercise of papal rights by explicitly acknowledging them by the church and regalism who based their law on the unremarkable custom and practice of using it as their own prerogative $^{19}$. It should be emphasised that in practice in the Spanish colonies in New India, the regalism approach prevailed and was so strong that the royal administration had a decisive voice in many matters from the spiritual order, i.e. the selection of members of the convention and participation in its deliberations, the creation of a specific internal law of the church, and even consent to take over episcopal capitals before consecrating the papal candidate. ${ }^{20}$

This is clearly visible in the context of the policy of King Philip II, who did not consider the patronage to be a personal right but as an attribute of royal power assigned to the Crown. ${ }^{21}$ Therefore, the Church in the colonies was more connected and more strongly involved in the relationship with the royal authority than the papal one. During Spanish domination, the Pope's authority was respected but was almost nominal. Marcelino Menéndez Pelayo considered regalism to be "the administrative heresy," but he supported its presence in the colonies as being sufficiently justified. There was no doubt that in order to facilitate the defence and expansion of Christianity, this attitude was considered right and the missionaries were treated as state officials. ${ }^{22}$ This "heresy" does not seem to be a dangerous weapon against the Church in the hands of kings and their consciences enlightened by faith, but rather a series of abuses and excessive use of powers and their over-interpretation have caused the unauthorised interference of civil authority in various church matters, resulting in their partial dependence on the state. ${ }^{23}$

The attempts to overcome this disadvantage were the signed concordats in 1737 between King Philip V and Pope Clement XII, and in 1753 between Pope Benedict XIV and King Ferdinand VI. With regard to the second document, it should be emphasised that it explicitly indicated the Catholic kings of Spain as persons having the authority to appoint archbishops, bishops and others to the vacant capitals, but the Pope made canonical appointments. The provision of a clear range of subjective and particular patronage in the colonial period established the limits of the execution of this right, despite the fact that it was often violated in practice.

19 A. de la Hera, El Regalismo Borbónico en su proyección indiana (Colección Canónica del Estudio General de Navarra 3), vol. 1, Madrid 1963, p. 119.

20 S. de Estrada, Nuestras relaciones con la Iglesia: hacia un concordato entre la Sede Apostolica y el Estado argentino, Buenos Aires 1963, pp. 75-92.

${ }^{21}$ M. Giménez Fernández, Las regalias mayestáticas en el Derecho Canónico indiano, "Anuario de Estudios Americanos" 1950, no.VI, p. 801.

22 A. de la Hera, R.M. Martinez de Codes, La Iglesia en el ordenamiento jurídico de las Leyes de Indias, [in:] Recopilación de leyes de los reynos de las Indias. Estudios histórico-jurídicos, F. de Icaza Dufour (ed.), México 1987, pp. 103-109.

23 M. Menéndez y Pelayo, Historia de los heterodoxos españoles. Regalismo y Enciclopedia; edición preparada por E. Sánchez Reyes, Madrid 1948; F. Cantelar Rodriguez, El patronato regio de indias en Solórzano Pereira, [in:] De Indiarum iure: (Liber III, De retentione Indiarum), J. de Solórzano Pereira (ed.), Madrid 1994, pp. 195-197. 
There are divergent concepts among doctrines regarding whether patronage should be considered a secular or church institution. The statement of Juan de Solórzano Pereira seems correct, according to which the first natural reaction would be to assign patronage to canon law because it is admitted by the Pope and the kings act on his behalf. Additional privileges in the form of tithing also have their source in the material goods of the Church. However, getting deeper into the essence and meaning of this institution, we doubt ourselves about the true nature of patronage. ${ }^{24}$ The power is passed on to lay people and they exercise it in this way. Moreover, in the event of there being insufficient tithing funds, the monarchs supplemented the deficiencies of the royal treasury. ${ }^{25}$

Distinguishing the above issue is not only a theoretical issue. Assuming that patronage is an element of ecclesiastical law, as a consequence, the Pope would be deprived of this privilege without providing justification for his actions. This issue applied throughout the existence of patronage (first royal and then national) in Argentina for the exercise of the powers arising from it because each party - state/king/ church - considered the source of this right to be in a different place.

Nevertheless, successive popes continued to grant patronage rights to the lands of New India, doing so in good faith and within their powers, and the kings accepted this gesture as an obvious and natural course of events. The most important privilege associated with filling the episcopal capitals provided the opportunity to protect the patronage and keep it unchanged for the next few years. The monarchs chose clerics who not only favourable to them but were above all advocates of the status quo who zealously defended patronage against changes, for example, during the Council of Trent.

\section{Constitutional grounds for introducing national patronage in Argentina}

The Constitution of Argentina from 1853, in addition to defining the institutional position of the Catholic Church, formally introduced the patronage of the Argentine legal system. ${ }^{26}$ This does not change the fact that from 1810 onwards, subsequent governments exercised these rights based only on the custom and legal tradition. ${ }^{27}$ Its foundations are to be found in the royal patronage granted by the popes to the kings of Spain since the beginning of their presence in America.

${ }^{24}$ C. Chacaltana, Patronato nacional argentino. Cuestiones de actualidad sobre las reciprocas relaciones de la Iglesia y del Estado, Buenos Aires 1885, p. 148.

25 F. Cantelar Rodriguez, op. cit., p. 196.

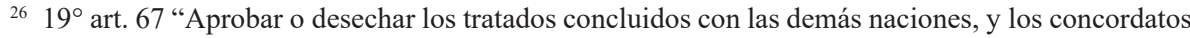
con la Silla Apostólica; y arreglar el ejercicio del patronato en toda la Confederación”; $8^{\circ}$ art. 86 "Ejerce los derechos del patronato nacional en la presentación de Obispos para las iglesias catedrales, a propuesta en terna del Senado."

27 Above all, in matters related to episcopal appointments, Catholic education, places of religious worship. J.L. Kaufmann, La presentación de obispos en el patronato regio y su aplicación en la legislación argentina, Buenos Aires 1996. 
The constitutional norms gave the president the right to present the Holy See with the list of bishops that the members of the Senate prepared. In addition, the executive power had the right to grant the consent of refusal of decrees, bulls, briefs and papal referees, in which the opinion of the Supreme Court was taken into account. ${ }^{28}$

A commitment to provide financial support for Roman Catholic worship, sanctioned in art. 2 of the Constitution, was in accordance with the government program. From a legal point of view, this decision was closely related to the desire to maintain patronage over the Catholic Church, including the right to present candidates for bishops and other services in the territory of Argentina.

The material help of civil authority for churches, which existed for many years as it was inherited from the colonial period, became an important legal basis for the possibility of influencing their self-government. This explains why this type of support and patronage were part of the constitutional text. Funding did not cover the entire ecclesiastical structure but only those areas that the state deemed necessary for maintaining control, i.e. the diocesan authorities and evangelisation. In the latter case, it was a tool for searching for new lands outside the country's indigenous border. The benefits from the parish were not taken into account because the state did not consider these organisational units as important for preserving the influence of church institutions in general. The interest of the state in the economic structure of the Church was in line with the broader plan of building state institutions. Therefore, attention was paid to the renovation of churches in the provinces because these were buildings that played the role of not only places of religious worship but also testified to the prosperity of the community and the entire social environment. In addition, they held important state functions such as the registration of births and marriages. This financial support and an increase in the amount allocated for worship in the annual budget approved by Congress allows the conclusion that the government undertook the task of creating a centralised and hierarchical structure of the Church, which was subordinated to state power. The decision on regarding the allocation of financial assistance to the Catholic Church in the Confederation was dictated by the influence of the Gallicanism concept, but it is worth noting that the Argentinian version seems to be more than just a government program. It was a broad venture based on the assumptions of the division of economic resources with the simultaneous coordination of various possible political concepts.

The exercise of patronage has been recognised by the Republic as a right derived from the constitution. The Holy See, however, did not share this opinion because the patronage was a personal privilege granted only by the Pope and only by way of a concordat. The Holy See, for its part, never endorsed this authorisation of the Argentine government, and in turn, secular authority derived them from the principle of state sovereignty, which was independent of any agreements or concessions of the Church. This profound discrepancy lasted over one hundred years, although the practical difficulties were partially overcome by modus vivendi, which allowed the preservation of canonical norms without changing the constitutional basis.

28 J.M. Ghio, La iglesia católica en la política argentina, Buenos Aires 2007, pp. 24-25. 
Relations between the Argentine Republic and the Holy See began to be regulated from 1853, when the first constitutional government sent a mission led by Juan Bautista Aberdi to Rome to end a long period of lack of communication following the May revolution in $1810 .{ }^{29}$ This, and the subsequent missions that followed, tried to reach an agreement with the Holy See, including with regard to establishing a diocese and filling episcopal capitals. However, the road to signing the concordat remained long due to divergent positions presented by both parties in the context of the patron's rights. To a lesser extent, it was about its implementation because the government did not obey strictly possessed powers but the prerogative itself was important as an attribute of supreme authority over the particular church. Therefore, this conflict should be regarded as existing at a strictly legal level because in practice, apart from the dispute with the government of Marcelo T. de Alvear from 1925, ${ }^{30}$ there was a modus vivendi until the 1960s which governed the issue of patronage. This informal arrangement arose from the fact that the president observed the rules of presentation, but he knew in advance the name of the prelate whom the pope wanted to designate. Therefore, he did not violate canon law by proposing another candidate for the episcopal capital. ${ }^{31}$

\section{Application of the patronage law in Argentina}

The official governmental position regarding the patronage law was not always described as their own or inherited entitlement. One should also take into account other views regarding the right of patronage in Argentina after 1810. ${ }^{32}$

As an example of an alternative view, it is worth considering the nominations of Bishop Mariano Medrano as Apostolic Vicar in the diocese of Buenos Aires, which was the first nomination made directly by the Pope. ${ }^{33}$ Additionally, in decrees signed by the Minister of Foreign Affairs, Tomás Manuel de Anchorena, with the governors of the province of Buenos Aires, it was stated that the province cannot independently change the provisions derived from ancient Spanish laws because then different arrangements and political positions were made for the dioceses that are now in the territories of five independent provinces. They do not now have these special royal powers that resulted from patronage and are therefore unable to execute them. The legal basis of the royal patronage has also been provided. In accordance with all

29 R.D. Carbia, La revolución de Mayo y la Iglesia, Buenos Aires 1945.

30 J.E. Gallardo, Conflicto con Roma (1923-1926). La polémica por Monseñor de Andrea, Buenos Aires 2004.

31 J.M. Gramajo, Los acuerdos celebrados entre la República Argentina y la Santa Sede, [in:] La libertad religiosa en el Derecho argentino, R. Bosca, J.G. Navarro Floria (eds.), Buenos Aires 2007, p. 66.

32 I. Martínez, El ejercicio del patronato y las mutaciones de la soberanía en la Argentina confederada, "Investigaciones y Ensayos" 2015, vol. 61, no. 1, pp. 44-46.

33 The Governor of the Province of Buenos Aires, Juan José Viamonte, on 10 April 1829, asked Pope Pius VIII to appoint a new bishop of the diocese. On 7 October 1829, the Pope appointed Mariano Medrano as bishop but in the nonexistent diocese of Aulón in order to avoid discussions with the government of Buenos Aires regarding the patronage. Along with this title, he also gave him the role of an apostolic vicar, a direct representative of the Pope to the government. R.D. Carbia, op. cit., pp. 133-135. 
honorary rights, titles and rights for Bishop Medrano in the diocese of Buenos Aires have been confirmed and guaranteed. ${ }^{34}$ This was not an isolated case because some of the governors were asking the Pope for the establishment and appointment of dioceses in their provinces. ${ }^{35}$

After the Constitution of 1853 came into force, the Confederacy government tried to strengthen its title to the patronage right by signing the concordat, but the issue of exequatur was an challenge not to be missed. The inability to communicate freely with the Holy See and the particular church was a fundamental obstacle to regulating diplomatic relations with Argentina. In 1861, after the territorial reorganisation and collapse of the Confederacy, the plans were no longer returned and the status quo was preserved.

The performance of patronage meant the nomination or presentation of diocesan bishops by the patron. From the point of view of relations with the Holy See, this is one of the most important powers because all other institutions and the entire ecclesiastical hierarchy are subordinate to the episcopate. The appointment to the episcopal capital was never transferred to the patron as an entitlement; it is inalienable and belongs exclusively to the Pope. It is important to distinguish the two spheres because not only the honesty but also the importance of filling the vacant episcopal capital depends on maintaining the correct canonical procedure.

In the Constitution, the procedure of cooperation between the president and the senate was taken into account; thus, the head of state alone would not be able to choose candidates. However, even the fulfilment of constitutional requirements did not make this right recognisable as belonging to secular authority. The Holy See did not pay attention to the procedure created in the course of constitutional changes because in reality, the nominations were performed using other, less formal means.

The preservation of strong relations between the Argentinian state and the Holy See required concessions on both sides to exercise the right of patronage. Candidates for bishops presented by the president in accordance with the will of the senators were those whom the pope wanted to nominate. Therefore, it appears that separate procedures have been maintained for each authority, but in practice, we can think of this as being a cooperation. Theoretically, the Pope did not recognise the presentation, and for the Argentine government, this law has not changed since the times of King Philip V. Until 1959, the official formulas of the presentation were so stringent that they envisaged the President signing a request to the Pope to confirm the list of candidates and the election of the bishop in accordance with canon law. At that time, the government, having unofficial information about the nominee's name, prepared a decree indicating that person.

The changes introduced in 1958 arose from the need to adapt the requirements to the new reality and the principles of canon law. These concerned documents and

${ }^{34}$ Signed with Governor Juan Ramón González Balcarce on 31 January 1831 and with Governor Juan Manuel de Rosas on 23 March 1831.

35 The Pope gave the government the privilege of presenting the name of a candidate for a bishop, provided that in addition to meeting formal appearance requirements, the government itself and its chairman would be Catholics in the community and obedient to the Holy See. O. Cavada, El Concordato de San Juan de Cuyo (Argentina) (1883-1884), "Estudios" 1962, no. 18, pp. 243-255. 
procedures as well as the archaic language used since colonial times. A more precise and adequate vocabulary was adopted. The main coordinator of the transformation was Miguel Angel Centeno, who was then undersecretary for the cult. ${ }^{36}$ In 1961, the presidential presentation was abolished and replaced with the duty of submitting appropriate noted by the Ambassador of the Holy See to the Secretariat of State, which in fact corresponded to the Argentine government's approval of the choice made by the Pope.

In accordance with these decisions, starting from 1959, the Senate meetings devoted to the preparation of episcopal letters were secret. Previously, they had been given publicity, which was part of a political demonstration. At the same time, the idea of adapting legal norms to new practical solutions in the form of an organic law arose. Due to the fact that on the part of the Holy See there could be a misunderstanding and interpretation of this action as an attempt to legalise patronage, this idea was quickly abandoned. However, the name of the Directorate for National Patronage (Dirección de Patronato Nacional), which was dependent on the Ministry of Foreign Affairs, was changed for the Directorate of Catholic Worship (Dirección de Culto Católico).

As far as the creation of new dioceses is concerned, it should be noted that in practice, the Argentine government did not oppose the Holy See's freedom of decision making from the very beginning. From 1855, when the law was issued on the Diocese of Paraná, which was canonically established in 1859, the law did not change. The regulation of procedures took place only in 1961 and resulted in the law being rewritten adapted the law written to the practice of the government. ${ }^{37}$ Since then, in the process of creating new archdioceses and dioceses, not only was the legal language modified but a different interpretation of constitutional provisions was also shown. This is also evident from the actions taken by the president, who sent a letter of thanks from the nation and the government to the Pope to express gratitude for the establishment of the new dioceses. In this way, he recognised the initiative of the Pope and interpreted it as a blessing for the Argentinian people.

Despite numerous disputes and discussions lasting for many years regarding the right of patronage in Argentina, it should be acknowledged that its practical application was of little importance. The institute was not sufficiently capable of achieving the goals intended by the government and later even omitted by it. It can even be described as ineffective and harmless, but it is worth noting that the more it lost its practical importance and the Church freed itself from the ties of political power, the more the legal foundations of constitutional regalism were deepened.

Despite the above, the growing ignorance in relation to canon law and the historical background of mutual relations caused the misinterpretation (over-interpretation)

${ }^{36}$ Instead of formulating the "appointment of a bishop" ("nómbrase obispo"), was used in 1959 the formula "to review the bishop's office" ("revistará en el cargo de obispo") which was necessary for budgetary purposes existing under the administrative provisions.

37 It is worth comparing Law 15804 of 1962 with Law 11715 of 1933: "autorízase al Poder Ejecutivo Nacional a proceder por los trámites civiles y a gestionar ante la Santa Sede los trámites canónicos necesarios para la creación de las siguientes nuevas diócesis, etc." and "El Poder Ejecutivo procederá, por los trámites civiles y canónicos, a la ereción de las siguientes nuevas diócesis, etc.” 
of constitutional norms. It is prohibited to apply an expansive interpretation based on errors and prejudices accumulated over many years. ${ }^{38}$

Objectively, it is necessary to reliably examine the terminology used in the Constitution in order to determine its meaning, especially art. 67 para. 19, which obliged the Congress to "adapt patronage throughout the country." From this clause, it can be concluded that the legislative authority was still entitled to unilaterally regulate the position of the Church in the country, in so far as it concerned its relations with public authorities at the national and provincial level, and to limit those church powers that would compete with the state administration in relation to the exercise of canon law. This clause also provides for the definition of norms and procedures not only directly concerning the episcopal capitals but also other benefits, such as the establishment of powers of relevant provincial offices as vice-patrons. ${ }^{39}$

It should be emphasised that both the text of the Constitution and the will of its creators indicate that this right was granted to Congress only when a given issue could not be resolved unilaterally and would require the participation of two or more entities. This meant that it only concerns acts that require the participation of other sovereign authorities. The constitutional norms adopted in this form did not theoretically limit the possibility of negotiating another form of cooperation with the Catholic Church. In practice, however, it would be difficult for both parties to come to an agreement. It is highly probable that the Holy See would not agree to grant the Argentine government the right of patronage to the extent that it would expect.

The exercise of this right in Argentina, even after the adoption of the new constitution, was improvised. It was not possible to adapt all the provisions to the new social and legal reality. In particular, in the context of liberal rule, it is difficult to talk about the interference of power in the sphere of church laws. Apart from the few obstacles stemming from the patronage and regalism law, the Catholic Church in Argentina also enjoyed freedom and respect from the rulers. Despite difficult periods in the history of the state and anti-clericalism in the years $1882-1890^{40}$ and $1954-1955,{ }^{41}$ both entities maintained good will with regard to maintaining the guarantee of internal order and social peace for the well-being of the state and the nation. ${ }^{42}$

${ }^{38}$ In terms of religious freedom vid. Sentences of Supreme Court of Argentina 53:188 in re J. Correa, R. Saba, Neutralidad del estado, igualdad de trato y tolerancia en materia religiosa, "Revista Jurídica de la Universidad de Palermo" 2000, Special issue dedicated to the Seminar in Latin America of Constitutional Theory and Politics, p. 279; H.R. Bermúdez, La libertad religiosa en la Constitución Nacional, [in:] La libertad religiosa en el Derecho argentino, R. Bosca, J.G. Navarro Floria (eds.), Buenos Aires 2007, pp. 94-95.

${ }^{39}$ C. Chacaltana, op. cit., p. 224.

${ }^{40}$ The relationship with the Holy See was discontinued in 1884 through the Minister of Justice, Eduard Wilde. He imposed himself to deposit the vicar general of Cordoba for his opinions against the appointment of teachers; R. Di Stefano, El pacto laico argentino (1880-1920), "PolHis" 2011, no. 8, pp. 80-89.

${ }^{41}$ In 1954, President Juan Domingo Peron began to conduct official campaigns against the Church, i.e. anti-clericalism, the right to divorce, restrict religious education, etc. Many Catholics were arrested and expelled from the country; S. Bianchi, Catolicismo y peronismo: la religión como campo de conflicto (Argentina, 1945-1955), Buenos Aires 2001; A. Mason, El conflicto de la jerarquía de la Iglesia con el Peronismo, "Diversidad" 2012, no. 4, pp. 82-114.

${ }^{42}$ J. Zanca, R. Di Stefano, Iglesia y catolicismo en Argentina. Medio siglo de historiografia, "Anuario de historia de la Iglesia" 2015, vol. 24, pp. 26-27. 


\section{Liquidation of patronage}

The first bilateral agreement between the Argentine government and the Holy See was reached on 28 June 1957 and concerned military jurisdiction and religious assistance in the armed forces. ${ }^{43}$ This document was important because it included the agreement of both parties to establish an agreed regime to fill the episcopal capital for the first time in the history of an independent republic. This agreement was modified with the help of Notas Reversales from 1992 to bring its contents into line with the provisions of the Apostolic Constitution of John Paul II, "Spirituali Militum Cura."

From 1958, during the reign of President Arturo Fondizi, Argentina began to engage in talks with the Holy See to resolve the issue of patronage, thus enabling the Pope to freely appoint bishops without interfering with civil authorities. On the Argentine side, they were led by Undersecretary of Cult, Dr Angel Centeno and Ambassador to the Holy See, Santiago de Estrada. The Holy See was represented by the secretaries of state, Cardinals Domenico Tardini and Amleto Cicognani and later Cardinal Umberto Mozzoni. The final text of the agreement was negotiated by Chancellor Miguel Zavala Ortiz during the presidency of Arturo Illia. The treaty regulated the following procedures: the free appointment of bishops by the Holy See; the construction and modification of ecclesiastical districts; the independence of bishops in inviting religious congregations and dioceses and diocesan priests to the country. The overthrow of President Illia's government prevented the signing of this agreement. ${ }^{44}$

The issue of national patronage in Argentina was formally completed by signing the concordat on 10 October 1966 by minister Nicanor Costa Méndez and the apostolic nuncio Humberto Mozzoni. This treaty remains in force to this day and is one of the most important legal acts regulating relations between the state and the Catholic Church in Argentina. ${ }^{45}$ It was founded on the basis of the principles of autonomy and cooperation between the Church and the State, proclaimed by the Second Vatican Council, and it created the basis for introducing friendly separation between the parties. ${ }^{46}$

The removal of the already anachronistic constitutional provisions concerning patronage occurred on the occasion of the constitutional reform in $1994 .{ }^{47}$ Until then, the doctrine recognised that a kind of "constitutional mutation" was created, according to which, the norm of international law stated the impossibility of applying these norms because of desuetude. ${ }^{48}$ In practice, regardless of the point of view of the regulatory hierarchy, between the conclusion of the agreement and the constitutional reform (1966-1994), no questions or doubts were raised between the parties regarding a possible contradiction of the agreement with the constitution.

${ }^{43}$ Decreto - Ley 7.623/57.

44 J.M. Gramajo, op. cit., p. 67.

45 Approved by Law 17.032, ratified on 28 January 1967 by Argentina.

${ }^{46}$ N. Padilla, A treinta años del acuerdo con la Santa Sede, http://www.calir.org.ar/verPdf.php?doc=/ docs/pubre106001.pdf [access: 7.08.2018].

47 J.G. Navarro Floria, Derecho eclesiástico y libertad religiosa en la República Argentina, [in:] Estado, derecho y Religión en América Latina, J.G Navarro Floria (ed.), Buenos Aires-Madrid-Barcelona 2009, p. 56.

${ }^{48}$ G.J. Bidart Campos, Manual de la Constitución Reformada, Buenos Aires 1996, pp. 43-44. 


\section{Assessment of the law of the Argentina patronage and conclusion}

Spain, which for more than three hundred years had a vast colonial empire on the American continent under its rule, lost its influence in it just over a decade ago. The problems that arose at that time did not omit the legal system, including the institution of patronage. Contrary to the concept of personal privilege, successive governments have used the powers of the Spanish monarchs in this regard, considering themselves to be their heirs. Both clerics and lay people were used to the fact that all disputes under canon law were settled by the India Council, audiences and vicekings. Therefore, after breaking off the relations with the metropolis, they naturally agreed that the proper authorities would still be secular authorities of the already independent republic. ${ }^{49}$

The constitutional norms regarding the patronage law over the years have roused numerous controversies and lively debates, which are mostly critical of doctrines and practices. There were numerous voices affirming that the Argentine patronage (in the sense of the national patronage) has never existed, because the key and necessary element of this right is the guarantee of a personal privilege, which is not hereditary. Thus, the Regio Patronato Indiano was not a territorial law but a common privilege of the Spanish monarchs. Just as new entities in international law do not inherit debts or other obligations of their predecessors, the same is true in this case. The patronage was an agreement of the "do ut facias" nature between the Catholic Church and Spain. On the one hand, the pope entrusted this law to the king, and on the other hand, the monarch committed himself to the creation, maintenance and financing of new churches and dioceses and to conduct evangelisation. This type of agreement remains valid as long as both parties exist and wish to maintain its provisions. Therefore, it cannot be assumed that the Argentine government was the Catholic King of Spain, nor that the Pope upheld the will to grant the same privilege as he did before. In connection with the change of one of the entities from an actual person (king of Spain) to an undefined collective entity, which was the government (not even just the President themselves), it would be difficult to maintain the continuity of the exercising of the right. Therefore, patronage cannot be an element of state sovereignty because if that were the case, each state would have to have such a right not to lose its sovereignty.

Another argument confirming the invalidity and ineffectiveness of the patronage law in Argentina was the standard included in art. 64 of the Constitution of 1853, under which the independence of the Catholic Church was recognised. According to this standard, Congress was entitled to "approve or reject treaties concluded with other nations and concordats with the Holy See." In addition, the Argentine government then maintained diplomatic relations with the Holy See. Importantly, the practical limitation of the sovereignty of the particular church concerned only Catholic units because other free religious associations decided about the choice of priests for higher positions or constituted their internal law without interfering with the secular power.

49 J.C. Zuretti, Historia eclesiastica argentina, Buenos Aires 1945, p. 183. 
It can also be argued that if the patronage was to be performed in accordance with Argentine law, it could not exist. According to art. 86 para. 9 of the Constitution of 1853, part of the doctrine believed that the norms of the Code of Canon Law of 1917 cannot be applied in Argentina because the "Provida Mater Ecclesia" bull has not been accepted into the Argentine law system. However, in the context of the provisions of the Council of Trent and their application in Argentine law, the Supreme Court issued a verdict on 6 February 1925 stating that "the provisions of the Council of Trent... are the law applicable in the country." ${ }^{50}$ While the conciliar arrangements (chapter XI, session XXII) deprived the lay persons the privilege to present and administer benefits, regardless of their dignity. The Council's regulations presented a number of norms in the field of patronage law, among others, the prohibition to give gifts in the future, and persons possessing the patron's rights were encouraged renounce it. The Council also introduced the requirement for the passage of 50 years as a condition of expiration for the introduction of the right of patronage.

It is possible to come to absurd conclusions by analysing the manner of exercising patronage law, which was used in Argentina, especially suggesting the nomination of Catholic bishops by the Senate, which could consist of senators with different religious beliefs or even non-believers biased towards the phenomenon of religiosity.

Considering both constitutional norms and the exercise of patronage by successive governments in Argentina, it should be recognised that in reality, this right was not based on the traditional model of the patronage institution granted by the Pope. On the one hand, it was an expression of the continuation of Argentine Catholic traditions, and on the other hand, it was a form of control and limitation of the influence of the particular Church. The doubtful basis of national patronage over time increasingly gravitated to state authorities, but their change (in the sense of liquidation) was difficult due to respect for its authority. As a result of the above, for many years, legal norms regarding patronage, including constitutional norms, were a legal fiction not reflected in practice and not matching the changes taking place in the system of statechurch relations. Nevertheless, the analysis of the issue concerning the theory and practice of patronage law in Argentina is important not only for historians but also for lawyers. It enables understanding of the current legal-religious model functioning in Argentina, as well as the correct interpretation of the provisions of the Argentine religious law.

\section{References}

Bermúdez H.R., La libertad religiosa en la Constitución Nacional, [in:] La libertad religiosa en el Derecho argentino, R. Bosca, J.G. Navarro Floria (eds.), Buenos Aires 2007, pp. 75-118.

Bianchi S., Catolicismo y peronismo: la religión como campo de conflicto (Argentina, 1945-1955), Buenos Aires 2001.

Bidart Campos G.J., Manual de la Constitución Reformada, Buenos Aires 1996.

Bruno C., El derecho público de la Iglesia en la Argentina, Buenos Aires 1956.

${ }^{50}$ Sentences of Supreme Court of Argentina, part XIX, t. 127-142, Buenos Aires 1925, p. 585. 
Buteler J., Patronato, Córdoba 1892.

Cantelar Rodriguez F., El patronato regio de indias en Solórzano Pereira, [in:] De Indiarum iure: (Liber III, De retentione Indiarum), J. de Solórzano Pereira (ed.), Madrid 1994, pp. 193-208.

Carbia R.D., La revolución de Mayo y la Iglesia, Buenos Aires 1945.

Casiello J., El problema de la coexistencia y de las conexiones entre la soberanía temporal y la soberanía espiritual y su solución en el caso argentino, Córdoba 1948.

Casiello J., Iglesia y estado en la Argentina. Regimen de sus relaciones, Buenos Aires 1948.

Casiello J., Iglesia y estado en la Argentina, régimen de sus relaciones, Buenos Aires 1958.

Cavada O., El Concordato de San Juan de Cuyo (Argentina) (1883-1884), "Estudios" 1962, no. 18, pp. 243-255.

Chacaltana C., Patronato nacional argentino. Cuestiones de actualidad sobre las reciprocas relaciones de la Iglesia y del Estado, Buenos Aires 1885.

Correa J., Saba R., Neutralidad del estado, igualdad de trato y tolerancia en materia religiosa, "Revista Jurídica de la Universidad de Palermo" 2000, Special issue dedicated to the Seminar in Latin America of Constitutional Theory and Politics, p. 279.

Derecho y religión. Derecho eclesiástico argentino, J.G. Navarro Floria, N. Padilla, O. Lo Prete (eds.), Buenos Aires 2014.

Duve T., El Tratado de Tordesillas: ¿Una 'revolución espacial'? Cosmografía, prácticas jurídicas y la historia del derecho internacional público, "Revista de Historia del Derecho" 2017, no. 54, pp. 77-107.

Dyjakowska M., Privilegium odiosum. O znaczeniu kontekstu $w$ przekładzie terminologii prawniczej, "Roczniki Humanistyczne" 2013, vol. LXI, no. 8, pp. 149-161.

Estrada S. de, Nuestras relaciones con la Iglesia: hacia un concordato entre la Sede Apostolica y el Estado argentino, Buenos Aires 1963.

Fernández de Landa T., Las relaciones entre la iglesia y el estado, Buenos Aires 1958.

Gallardo J.E., Conflicto con Roma (1923-1926). La polémica por Monseñor de Andrea, Buenos Aires 2004.

García-Gallo A., Las Bulas de Alejandro VI y el ordenamiento juridico de la expansión portuguesa y castellana en África e Indias, “Anuario de Historia del Derecho Español” 1958-1959, nos. 27-28, pp. 461-830.

Ghio J.M., La iglesia católica en la política argentina, Buenos Aires 2007.

Giménez Fernández M., Las regalias mayestáticas en el Derecho Canónico indiano, "Anuario de Estudios Americanos" 1950, no. VI, pp. 801-811.

Gramajo J.M., Los acuerdos celebrados entre la República Argentina y la Santa Sede, [in:] La libertad religiosa en el Derecho argentino, R. Bosca, J.G. Navarro Floria (eds.), Buenos Aires 2007.

Hera A. de la, El Regalismo Borbónico en su proyección indiana (Colección Canónica del Estudio General de Navarra 3), vol. 1, Madrid 1963.

Hera A. de la, Martinez de Codes R.M., La Iglesia en el ordenamiento jurídico de las Leyes de Indias, [in:] Recopilación de leyes de los reynos de las Indias. Estudios histórico-jurídicos, F. de Icaza Dufour (ed.), México 1987, pp. 103-140.

Kaufmann J.L., La presentación de obispos en el patronato regio y su aplicación en la legislación argentina, Buenos Aires 1996.

Lafuente R. de, El patronato y el pase o "exequatur" argentinos, [in:] La doctrina católica en el desenvolvimiento constitucional argentino, A. Caggiano (ed.), Buenos Aires 1957, pp. 203-216.

Legón F., Doctrina y ejercicio del patronato nacional, Buenos Aires 1920.

Leturia P. de, El origen histórico del Patronato de Indias, [in:] Relaciones entre la Santa Sede e Hispanoamérica, vol. 1: 1493-1800, Época del Real Patronato, Romae-Caracas 1959, pp. 1-29.

Martínez I., El ejercicio del patronato y las mutaciones de la soberanía en la Argentina confederada, "Investigaciones y Ensayos" 2015, vol. 61, no. 1, pp. 37-50. 
Mason A., El conflicto de la jerarquía de la Iglesia con el Peronismo, "Diversidad" 2012, no. 4, pp. 82-114.

Menéndez y Pelayo M., Historia de los heterodoxos españoles. Regalismo y Enciclopedia, E. Sánchez Reyes (ed.), Madrid 1948.

Navarro Floria J.G., Derecho eclesiástico y libertad religiosa en la República Argentina, [in:] Estado, derecho y Religión en América Latina, J.G Navarro Floria (ed.), Buenos Aires-MadridBarcelona 2009.

Padilla N., A treinta años del acuerdo con la Santa Sede, http://www.calir.org.ar/verPdf.php?doc=/ docs/pubrel06001.pdf [access: 7.08.2018].

Sentences of Supreme Court of Argentina, part XIX, t. 127-142, Buenos Aires 1925.

Stefano R. di, El pacto laico argentino (1880-1920), "PolHis" 2011, no. 8, pp. 80-89.

Zanca J., Stefano R. di, Iglesia y catolicismo en Argentina. Medio siglo de historiografia, "Anuario de historia de la Iglesia" 2015, vol. 24, pp. 15-45.

Zuretti J.C., Historia eclesiastica argentina, Buenos Aires 1945. 